\title{
METACOGNITION AND HAPPINESS: THE MEDIATING ROLE OF PERCEIVED STRESS
}

\author{
Hakan SARIÇAM \\ Faculty of Education, Dumlupinar University \\ Kütahya, 43100 Turkey \\ E-mail: hakansaricam@gmail.com
}

\begin{abstract}
The basic aim of this research is to examine the mediating role of perceived stress between metacognition and happiness. The participants were 290 university students. In this study, the Metacognition Questionnaire-MCQ-30, the Perceived Stress Scale and the Short Form of Oxford Happiness Questionnaire were used. The relationships between metacognition, perceived stress, and happiness were examined using correlation analysis and Structural Equation Model (SEM). In correlation analysis, metacognition and perceived stress were found to be negatively related to happiness. On the other hand, metacognition was found to be positively correlated to perceived stress. Structural Equation Model showed that metacognition results in an increase in perceived stress in an unhappy person, whereas reduction in stress leads to happiness; however, metacognition also produces unhappiness. Results were discussed in the light of the related literature.
\end{abstract}

Key words: metacognition, happiness, stress

\section{Introduction}

This research aims to investigate the mediating role of perceived stress between metacognition and happiness. It is based on the innovative idea that metacognitive beliefs or experiences may sometimes lead to persistent and maladaptive forms of coping, and therefore the relationship between perceived stress and emotion (in the context of the present study, happiness was preferred as an emotion) would be mediated by metacognitions. There is a considerable research gap in this area except for a few research studies (e.g., Wells, 1995). Previous studies have examined the relationship between individual dimensions of metacognition and psychological disorders such as anxiety (Sheikh et al., 2013), depression
(Papageorgiou \& Wells, 2003; Wells, 2009; Yilmaz, 2007), hypochondriasis (Bouman \& Meijer, 1999; Buwalda, Bouman, \& Van Duijn, 2008), obsessive-compulsive symptoms (Mohammadkhani, 2013; Wells \& Papageorgiou, 1998; Yılmaz, Gençöz, \& Wells, 2008), pathological worry (CartwrightHatton \& Wells, 1997; Wells \& Carter, 2001; Yılmaz, Gençöz, \& Wells, 2008), post-traumatic stress disorder (Holeva, Tarrier, \& Wells, 2001), psychosis (Morrison, Wells, \& Nothard, 2000), problem drinking (Spada \& Wells, 2005; Spada, Zandvoort, \& Wells, 2007), and test-anxiety (Spada, Nikcevic, Moneta, \& Ireson, 2006). However, the issue of how perceived stress mediates between metacognition and happiness has not been tested.

In this paper, I start by explaining the concepts of metacognition, stress and happi-

DOI: $10.21909 / \mathrm{sp} .2015 .03 .699$ 
ness, and continue with the presentation of the hypotheses of this research in relation to the study aim. Next, I present the methods of the study followed by the results. In the final section, I discuss the study findings in association with the related literature.

\section{Metacognition}

"Metacognition" has been a very popular term in psychology since the 1970s and it was presented by Flavell (1979); he defined metacognition as "knowledge and cognition about cognitive phenomena" (p.906). Metacognition refers to the knowledge, processes, and strategies that appraise, monitor, and control cognition (Flavell, 1979; Wells, 2000). Other definitions widely accepted in the literature are "thinking about thinking" and "cognition about cognition" (Brown 1987; Garner \& Alexander, 1989; Jacops \& Paris, 1987, Wellman (1985).

From a clinical psychology perspective, metacognition is defined as "the psychological structures, knowledge, events, and processes that are involved in the control, modification, and interpretation of thinking itself' (Wells \& Cartwright-Hatton, 2004, p. 385). In cognitive psychology, metacognition can be defined as "stable knowledge or beliefs about one's own cognitive system, and knowledge about factors that affect the functioning of the system; the regulation and awareness of the current state of cognition, and appraisal of the significance of thought and memories" (Wells, 1995, p. 302). However, meta-cognition does not have only positive structures but also negative ones (Sarıçam \& Akın, 2015). The metacognitive model of psychopathology is based on the theoretical account named Self-Regulatory Executive Function (S-REF,
Wells \& Matthews, 1994). The S-REF model describes mechanisms of problematic information processing that ultimately results in emotional disorders. The S-REF theory conceptualizes multiple metacognitive factors as control mechanisms of information processing that influences the development and persistence of psychological disorders. In the literature, it was observed that the S-REF theory has affected the development of current disorder specific models and treatment procedures of GAD, obsessions, depression, PTSD, and social phobia (Papageorgiou \& Wells, 2003; Holeva, Tarrier, \& Wells, 2001; Wells, 2000).

Wells and Cartwright-Hatton (2004) declared metacognition as composed of five correlated but conceptually distinct sub-dimensions: 1) Positive Beliefs about Worry, which assesses the extent to which a person believes that ruminative thinking is useful; 2) Negative Beliefs about Worry Concerning Uncontrollability and Danger, which measures the extent to which a person thinks that ruminative thinking is dangerous and uncontrollable; 3) Lack of Cognitive Confidence, assessing confidence in attention and memory; 4) Beliefs about Need to Control Thoughts; and 5) Cognitive Self-consciousness, which measures the tendency to monitor one's own thoughts and focus attention inwards.

\section{Stress}

Stress is frequently considered as the most common disease of the modern age. Although it has many definitions, one major category of stress is conceptualized as the existence of significant life events that are evaluated by the person as unwanted (Lazarus \& Folkman, 1984; Monroe \& 
Simons, 1991). That is to say, stress refers to a relationship with the environment that the person appraises as significant for his or her well-being and in which the demands tax or exceed available coping resources. According to another definition, stress is a person's adaptive response to a stimulus that places excessive psychological or physical demands on him or her (Moorhead \& Grifin, 1998).

Lazarus and Folkman (1984) have provided one of the most comprehensive elucidations regarding how people perceive an event as stressful or not. Authors debated personal and situational variables that influence appraisal. Although they investigated these two variables separately, they also centered upon their interdependency. Personal variables are commitments and beliefs. Situational variables are ambiguity, oddness, uncertainty, temporal factors, and the timing of stressful events in relation to the life cycle (Lazarus, 1991). Especially, personal factors are very important for this study in the context of metacognition. The second personal variable is beliefs about personal control which is named as self-control. When people do not feel mastery and confidence about their competence, they evaluate a difficulty as a threat or a challenge. If they believe that they can affect what happens during a difficult situation and manage the relationship between themselves and this situation, they can develop coping strategies easily. Thence, they do not interpret the situation as stressful. In other words, beliefs are momentous for perceived stress. Perceptions of stress and responses to them cause many psychological and health problems such as depression (Siegrist, 2008; Wolkowitz, Epel, Reus VI, \& Mellon, 2010), insomnia (Akerstedt, 2006), coronary artery disease (Rosengren, Tibblin,
\& Wilhelmsen, 1991), worry (Akerstedt, Kecklund, \& Axelsson, 2007), etc.

\section{Happiness}

Happiness as the ultimate aim of human actions is an argument which has been put forwarded since time immemorial. It has been held in acclaim by prominent sociologists, philosophers, economists, and psychologists, especially "social", "self" and "positive" psychologists. In sociology, happiness is associated with life quality (Veenhoven, 2005); in philosophy, happiness is related to the meaning of life (Kenny, 2006); in economics, happiness is examined at the point of welfare (Sumner, 1996). To be happy means to be glad or pleased with having a good measure which one regards as acute in life (Griffin, 2007). In this perspective, "happiness" is defined by the individual who explains why it varies from individual to individual. Therefore, it is known as a subjective concept in psychology. Happiness is often used in place of subjective well-being, a term in psychology (Lyubomirsky, Sheldon, \& Schkade, 2005; Sheldon \& Lyubomirsky, 2004; Sagiv, Roccas, \& Hazan, 2004). When human actions provide happiness, they had been praised; and when they provide unhappiness, they had been reviled (Lyubomirsky \& Tucker, 1998). Namely, happiness by this view is seen as an emotion combined with other positive emotions, resulting in subjective well-being. Diener (2000) identifies subjective well-being as positive emotions of a person exceeding negative emotions and life satisfaction.

Seligman's authentic happiness theory is a synthesis of the three happiness theories. First, pleasant life is about happiness in a hedonic sense; second, engaged life is about 
happiness through engagement; and, finally, meaningful life is about achieving virtue (Sirgy\& Wu, 2009). According to Seligman's (2002) authentic happiness theory, happiness has three determinants formulated as $\mathrm{H}=\mathrm{S}+\mathrm{C}+\mathrm{V}$ and it reveals that happiness is the sum of a set range, circumstances, and factors under voluntary control. In this balance, $S$ is the genetically determined determinant which is stable throughout life. $C$ identifies the circumstances such as getting married, having education or making more money. $V$ stands for the engagement with the voluntary activities performed with an effort.

\section{Present Study}

Considering the assertion that metacognitive beliefs or experiences may lead to persistent and maladaptive forms of coping as raised by the S-REF theory, Spada and his colleagues (2008) suggested that although stress is perceived as a maladaptive coping skill in the long term because of its negative consequences, in the short term, it may appear as an adaptive coping strategy to regulate withdrawal-related negative affect. Therefore, Spada and his colleagues (2008) hypothesized that the relationship between perceived stress and emotion (in the context of the present study, happiness was preferred as an emotion) would be mediated by metacognitions. The aim of this research is to examine the mediating role of stress between metacognition and happiness. Based on above literature, the following hypothesis is developed for this study:

Hypothesis 1. Sub-dimensions of metacognition will be positively associated with perceived stress.

Hypothesis 2. Perceived stress will be negatively associated with happiness.

Hypothesis 3. Metacognition will increase stress and this relation will negatively affect happiness. This model is represented schematically in Figure 1. On the other hand, alternative model is evaluated in Figure 2.

\section{Method}

\section{Participants}

The current research was carried out with a sample of 286 university students, 172 of whom $(60.14 \%)$ were female and $114(39.86 \%)$ were male students from different grade levels enrolled in different departments of the Education Faculty in Dumlupinar University

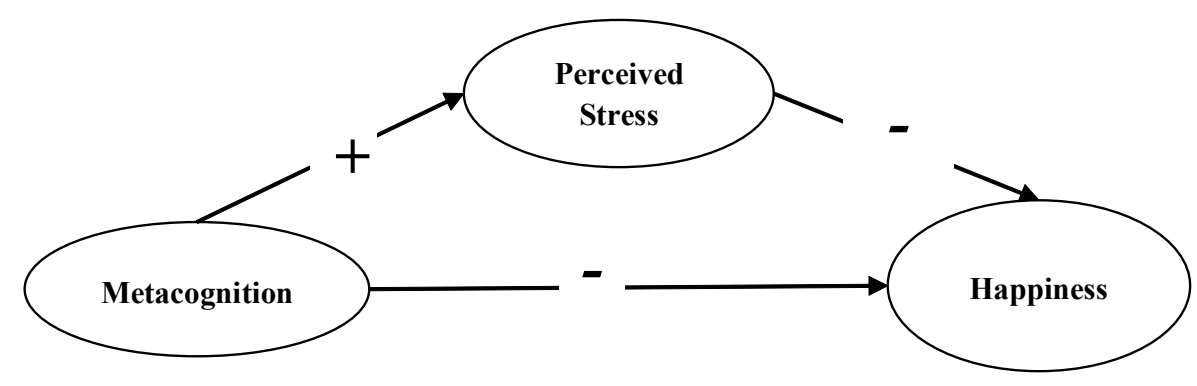

Figure 1 Hypothesized model of the relationships between metacognitions, perceived stress and happiness 


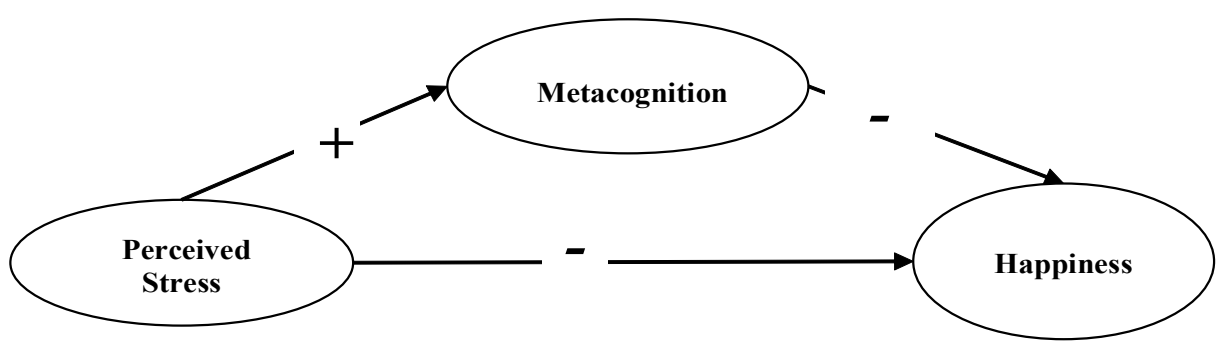

Figure 2 Alternative model of the relationships between metacognitions, perceived stress and happiness

in Turkey. The departments of these students were early childhood education $(n=94)$, social sciences education $(n=43)$, primary education $(n=106)$, and Turkish literature $(n=$ 43 ). Their ages ranged from 18 to 25 years with a mean age of 20.71 years. 34 students (11.89\%) were freshmen, $69(24.13 \%)$ were sophomores, and 183 (63.99\%) were seniors.

\section{Instruments}

The Metacognition Questionnaire-MCQ30 (Wells \& Cartwright-Hatton, 2004): It was developed to assess individual differences in metacognitive beliefs, judgments, and monitoring tendencies. The person rates himself or herself on a 4 point scale between 1 (do not agree) and 4 (agree very much), and the scores range from 30 to 120 . The MCQ30 consists of five correlated but conceptually distinct factors assessed by 30 items: 1) positive beliefs about worry, which measures the extent to which person believes that worrying is helpful (e.g., "Worrying helps me cope"); 2) negative beliefs about worry, measuring the extent to which the person believes that worrying is uncontrol- lable and dangerous (e.g., "When I start worrying I cannot stop"); 3) beliefs about lack of cognitive confidence, assessing confidence in memory, (e.g., "My memory can mislead me at times"); 4) beliefs about need to control thoughts and consequences of not controlling one's own thoughts, (e.g., "Not being able to control my thoughts is a sign of weakness"); and 5) cognitive selfconsciousness, which assesses the tendency to monitor one's own thoughts and focus attention inwards (e.g., "I pay close attention to the way my mind works"). The MCQ-30 was translated and adapted into Turkish by Tosun \& Irak (2008). The MCQ30 was also validated in both normal and clinical groups. According to CFA results, the goodness of fit index values of the model were $\chi^{2}[(465, N=850)=1282.91, p<.001]$ $\mathrm{RMSEA}=.051 ; \mathrm{CFI}=.90 ; \mathrm{GFI}=.90 ; \mathrm{RMR}=$ $.50 ; \mathrm{IFI}=.90 ; \mathrm{TLI}=.89$ ). The MCQ-30 has a good internal consistency and convergent validity as well as acceptable test-retest reliability. The Cronbach's alpha were found as $.85, .87, .81, .70, .65$, respectively. Three subscales are in acceptable range and the other is in poor range of reliability values. 
Perceived Stress Scale: Stress was measured by using Perceived Stress Scale developed by Cohen, Kamarck, and Mermelstein, (1983). Örücü and Demir (2009) did the Turkish adaptation of this scale. The scale consists of ten items (e.g., In the last month, how often have you felt nervous and "stressed"?), and each item was presented on a five-point Likert scale $(0=$ never, $4=$ very often). The total scores ranged from 0 to 40 , with higher scores indicating greater overall distress. The Turkish adaptation and validation of this instrument was carried out and the Cronbach alpha reliability coefficient for the Turkish version of the PSS-10 was found to be .84 .

Short Form of the Oxford Happiness Questionnaire: Happiness was measured by using the Short Form of Oxford Happiness Questionnaire (Hills \& Argyle, 2002). Doğan and Akinci Çötok (2011) did the Turkish adaptation of this scale. The scale consists of eight items (e.g., I am well satisfied about everything in my life), and each item was presented on a seven-point Likert scale $(1=$ strongly disagree, $6=$ strongly agree). The total scores ranged from 8 to 48 , with a higher score indicating higher happiness. The goodness of fit index values of the model were $\left[\left(\chi^{2} / d f=2.77, p=0.49\right) \mathrm{AGFI}=.97, \mathrm{NFI}=\right.$ $.92, \mathrm{CFI}=.95, \mathrm{IFI}=.95, \mathrm{GFI}=.93, \mathrm{RMSEA}=$ $.074, \mathrm{SRMR}=.044]$. The OHQ-SF's internal consistency coefficient and test-retest reliability coefficient were determined to be .74 and 85 , respectively.

\section{Procedure}

Permission for participation of the students was obtained from related departments. Students participated in the research voluntarily. Prior to the administration of the scales, all participants were informed about purposes of the study. Relationships between three variables (metacognitions, stress, and happiness) and their sub-dimensions were tested using the Pearson Product Moment Correlation Coefficient at .01 probability level, because data provided criteria of normality. Moreover, data were analyzed by means of structural equation modelling (SEM) using the AMOS 6 program. SEM is a statistical methodology that takes a confirmatory approach to the analysis (Byrne, 2010). In this approach a hypothesized model of relations between variables is tested statistically to determine the extent to which it is consistent with the data, which is referred to as the goodness of fit. If the "goodness of fit" is adequate, it supports the plausibility of the relations among the variables. To assess model fit, we used well-established indices such as CFI, IFI, TLI, and RMSEA as well as the chi-square test statistics. For the CFI, IFI, and TLI indices, values greater than .90 are typically considered acceptable and values greater than .95 indicate good fit to the data (Byrne, 2010; Hu \& Bentler, 1999). For well specified models, an RMSEA of .06 or less reflects a good fit (Hu \& Bentler, 1999). For the analysis of data SPSS 17 and AMOS 6 were utilized.

\section{Results}

\section{Inter-Correlations and Descriptive Data}

Table 1 shows the inter-correlations of the variables, means, standard deviations, and internal consistency coefficients of the variables used.

When Table 1 is examined, it is seen that there are significant correlations between dimensions of metacognition, stress, and 
Table 1 Descriptive statistics, alphas, and inter correlations of the variables

\begin{tabular}{|c|c|c|c|c|c|c|c|c|}
\hline Variables & 1 & 2 & 3 & 4 & 5 & 6 & 7 & 8 \\
\hline $\begin{array}{l}\text { 1. Positive beliefs about } \\
\text { worry (Pbw) }\end{array}$ & 1 & & & & & & & \\
\hline $\begin{array}{l}\text { 2. Beliefs about lack of } \\
\text { cognitive confidence (Blcc) }\end{array}$ & $.24^{* *}$ & 1 & & & & & & \\
\hline $\begin{array}{l}\text { 3. Negative beliefs about } \\
\text { worry (Nbw) }\end{array}$ & $.38^{* *}$ & $.52^{* *}$ & 1 & & & & & \\
\hline $\begin{array}{l}\text { 4. Cognitive self- } \\
\text { consciousness (Css) }\end{array}$ & $.45^{* *}$ & $.55^{* *}$ & $.54^{* *}$ & 1 & & & & \\
\hline $\begin{array}{l}\text { 5. Beliefs about need to } \\
\text { control thoughts (Bnct) }\end{array}$ & $.46^{* *}$ & $.35^{* *}$ & $.48^{* *}$ & $.51^{* *}$ & 1 & & & \\
\hline 6. Metacognition (Total) & $.57^{* *}$ & $.64^{* *}$ & $.70^{* *}$ & $.71^{* *}$ & $.68^{* *}$ & 1 & & \\
\hline 7. Perceived stress & $.26^{*}$ & $.58^{* *}$ & $.66^{* *}$ & $.45^{* *}$ & $.49^{* *}$ & $.60^{* *}$ & 1 & \\
\hline 8. Happiness & $-.18^{*}$ & $-.35^{* *}$ & $.36^{* *}$ & $-.32^{* *}$ & $-.30^{* *}$ & $-.40^{* *}$ & $-.62^{* *}$ & 1 \\
\hline Mean & 16.19 & 12.00 & 11.22 & 12.08 & 11.87 & 63.36 & 29.03 & 34.27 \\
\hline Standard deviation & 3.55 & 3.27 & 3.43 & 3.73 & 3.65 & 4.90 & 5.19 & 8.34 \\
\hline Alpha $(N=286)$ & .76 & .70 & .71 & .70 & .73 & .82 & .86 & .83 \\
\hline
\end{tabular}

happiness. Positive beliefs about worry $(r=$ $.26, p<.05)$, beliefs about lack of cognitive confidence $(r=.58, p<.01)$, negative beliefs about worry $(r=.66, p<.01)$, cognitive selfconsciousness $(r=-.45, p<.01)$, beliefs about need to control thoughts $(r=-.49, p<.01)$ were related positively to stress. On the contrary, stress was found negatively associated with happiness $(r=-.62, p<.01)$. There were also significant correlations between dimensions of metacognition.

\section{Structural Equation Modeling}

In the first step, the direct path from the predictor (metacognitions) to the dependent (happiness) in the absence of a mediator was significant, $\beta=-0.38, p<0.01$. Then the partially mediated model, which contained a mediator (perceived stress) and a direct path from metacognition to happiness was tested. The partially meditational model showed a good fit to the data: $\chi_{(110, \mathrm{~N}=286)}^{2}=216.78$, $p<.001 ;\left(\chi^{2} / d f=1.97, \mathrm{CFI}=.96, \mathrm{IFI}=.96, \mathrm{TLI}\right.$ $=.95$ and $\mathrm{RMSEA}=.052$ (Figure 3 )

Figure 3 shows that metacognition results in an increase of perceived stress in an unhappy person, whereas reduction in stress leads to happiness; however, metacognition also causes unhappiness. Moreover, perceived stress had a mediator and moderator role, because the correlation coefficient value $(\beta=-0.38)$ of metacognition decreased $(\beta=$ $-0.26)$.

To find the best model, the direct path from the predictor (perceived stress) to the dependent (happiness) in the absence of a mediator was significant, $\beta=-0.34, p<0.01$. Then 
the partially mediated model, which contained a mediator (metacognition) and a direct path from perceived stress to happiness was tested. The partially meditational model showed a poor fit to the data: $\chi^{2}{ }_{(96, \mathrm{~N}=286)}=$ $498.23, p<.001 ;\left(\chi^{2} / d f=5.19, \mathrm{CFI}=.86, \mathrm{IFI}=\right.$
$.87, \mathrm{TLI}=.85$, and $\mathrm{RMSEA}=.094$ (Figure 4).

In order to decide which model was preferred, $\chi^{2} / d f$ values were taken into account. First model's $\chi^{2} / d f$ value (1.97) was smaller than second model $\chi^{2} / d f$ value (5.19); first model was preferred.

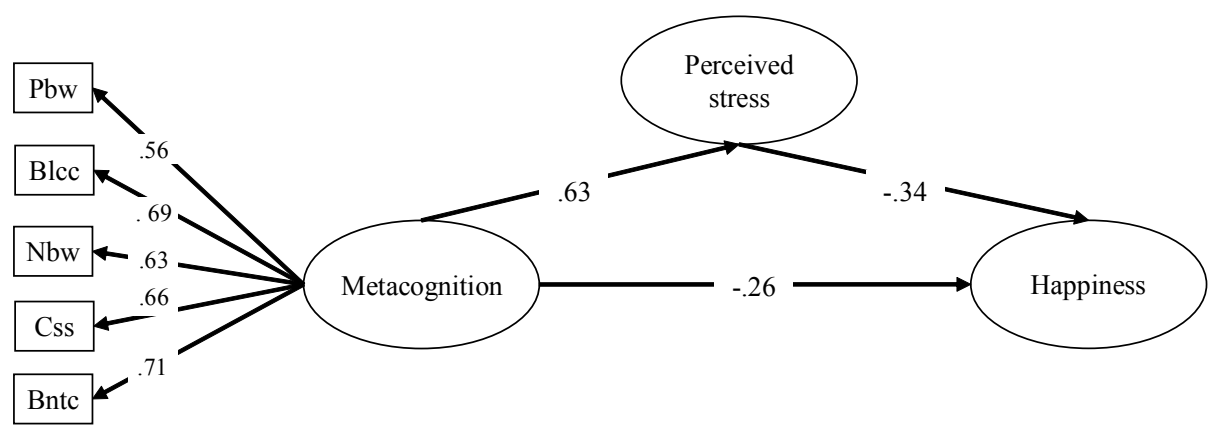

Figure 3 Path analysis of the mediating role of perceived stress in the relationship between metacognition and happiness

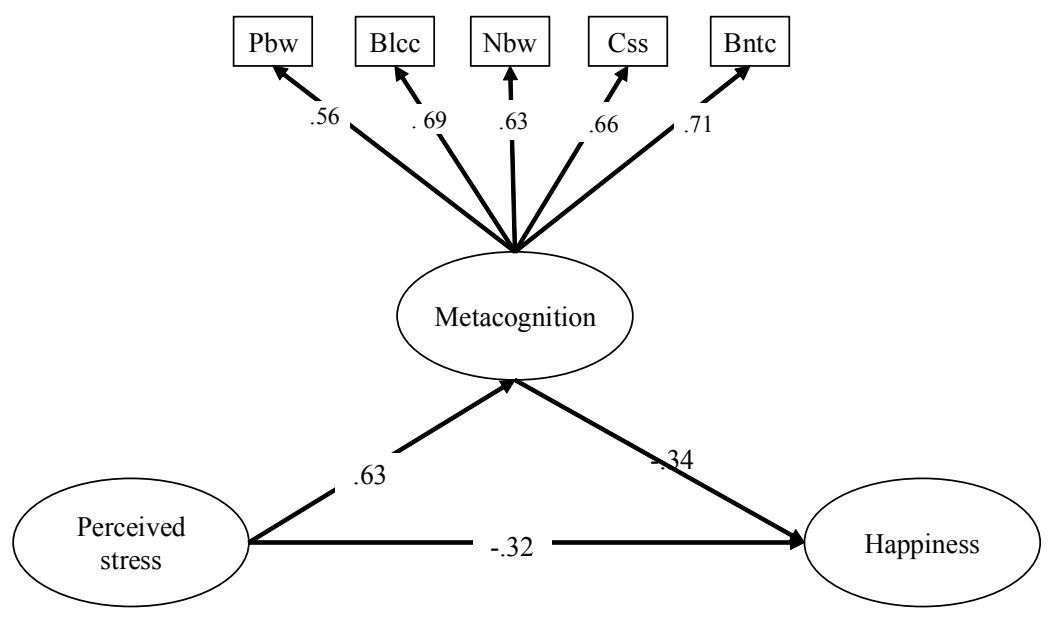

Figure 4 Alternative model of the mediating role of perceived stress in the relationship between metacognition and happiness 


\section{Discussion}

In this study, a structural equation model with perceived metacognition and stress variables was tested in order to explain happiness among university students. Results confirm that there are relationships among five sub-dimensions of metacognition and stress. Based on path analysis, it was concluded that happiness is decreased as a result of stress; metacognition levels have increased the level of stress, and a higher level of stress causes unhappiness. These findings are consistent with the findings of some authors (Matthews \& Wells, 2004; Mohammadkhani, 2013; Papageorgiou \& Wells, 2003; Wells, 2009; 2000).

The S-REF model emphasizes that vulnerability to and maintenance of all psychological disorders is causally associated with the tendency to and activation of a particular pattern of cognition, called Cognitive Attentional Syndrome (CAS; Wells 2000). The CAS comprises self-focused attention in the form of repetitive thinking styles of worry and rumination, reduced cognitive functioning, activation of dysfunctional selfbeliefs, persistent allocation of attention to internal and external sources of danger, and use of maladaptive coping strategies which hinder modification of dysfunctional beliefs (Matthews \& Wells, 2004). In other words, psychological disorders are maintained by selection and execution of maladaptive coping strategies, such as preservative thinking (e.g., rumination, obsession, and worry), attention allocation to threat monitoring, avoidance and thought suppression, which fail to modify dysfunctional self-beliefs and increase the accessibility of negative information about self(Wells, 2000; 2009). In other words, negative metacognitions have content in the form of negative self-cognitions like ruminative thinking (Kacar \& Sarıçam, 2015). The Metacognitive Theory maintains that nonfunctional beliefs about cognitions, which form the metacognitions, are central to the improvement and maintenance of psychological disorders (Wells, 2000; Wells \& Mathews, 1994). For example, these beliefs have also been found to be related to other distress phenomena, for instance, perfectionism (Flett, Hewitt, Blankstein, \& Gray, 1998), eating disorders (e.g., Vitousek, 1996), pathological gambling (Lindberg et al., 2011), physical symptoms of illness (Aydin, 1997), suicide-related responses (Nock \& Kazdin, 2002), seasonal affective disorder (e.g., Rohan, Sigmon, \& Dorhofer, 2003), and generalized anxiety disorder (Wells, 2004). Moreover, Wells' (2009) metacognitive therapy (MCT) model accentuates the importance of both cognitive and metacognitive dimensions of thinking. In accordance with this model, the notion of metacognition is believed to play a significant role in psychopathology (Wells, 2009; Wells \& Mathews, 1994). Briefly, dysfunctional metacognition has direct effect on stress (Roussis \& Wells, 2006; Spada, Nikcevic, Moneta, \& Wells, 2008) and indirect effect on well-being. On the other hand, anxiety, boredom, depression, discontent, dissatisfaction, sadness, and stress are obvious manifestations of unhappiness (Layard, 2005; Ricard, 2007; Seligman, 2002; Veenhoven, 1991). In this context, if dysfunctional metacognition causes psychological disorders such as anxiety, depression, stress, etc., it affects happiness, indirectly.

People with extreme responsibility for their thoughts can experience more distress and make catastrophic misinterpretation of thoughts (Mohammadkhani, 2013). On the 
other hand, perceived stress is negatively associated with happiness. The hypothesis related to the association between happiness and perceived stress was largely demonstrated, showing that participants who perceived higher levels of stress were less happy than those with lower levels of stress. These results are consistent with previous research studies showing there is a negative relationship between happiness and perceived stress manifested by self-reported measures (Blanchflower \& Oswald, 2008; Omidi, Akbari, \& Mahdian, 2011). In this context, metacognition is correlated to happiness, owing to stress.

This study has some limitations which should be considered when interpreting the results. First, the sampling procedure is not random. Thus, the generalizability of the results is limited. The second limitation is related to the participants, because the sample presented here is limited to university students at the Education Faculty.

In conclusion, this research reports that metacognition occurs as an augmentation of perceived stress in an unhappy person, whereas decrease in stress leads to happiness; moreover, metacognition also bears unhappiness. Students low in metacognition are more likely to experience low stress and happiness. That is why, an ongoing study would further my understanding of the notable forecasters of happiness, notwithstanding that more research is needed to examine the premises of metacognition and happiness.

Received November 29, 2014

\section{References}

Akerstedt, T. (2006). Psychosocial stress and impaired sleep. Scandinavian Journal of Work, Environment \& Health, 32, 493-501.
Akerstedt, T., Kecklund, G., \& Axelsson, J. (2007). Impaired sleep after bedtime stress and worries. Biological Psychology, 76, 170-173.

Aydin, G. (1997). The relationship between negative automatic thoughts and illness. International Journal of Mental Health, 25, 69-74.

Blanchflower, D. G., \& Oswald, A. J. (2008). Is well-being U-shaped over the life cycle? Social Science \& Medicine, 66, 1733-1749.

Bouman, T. K., \& Meijer, K. J. (1999). A preliminary study of worry and metacognitions in hypochondriasis. Clinical Psychology and Psychotherapy, 6, 96-101.

Byrne, B. M. (2010). Structural Equation Modeling with AMOS: Basic concepts, applications, and programming. New York: Routledge Taylor \& Francis Group.

Buwalda, F. M., Bouman, T. K., \& Van Duijn, M. A. J. (2008). The effect of a psychoeducational course on hypochondriacal metacognition. Cognitive Therapy and Research, 32(5), 689-701.

Cartwright-Hatton, S., \& Wells, A. (1997). Beliefs about worry and intrusion: The metacognitions questionnaire and its correlates. Journal of Anxiety Disorders, 11, 279-315.

Cohen, S., Kamarck, T., \& Mermelstein, R. (1983). A global measure of perceived stress. Journal of Health and Social Behavior, 24, 385-396.

Diener E. (2000). Subjective well-being: The science of happiness and a proposal of a national index. American Psychologist, 55, 34-43.

Doğan, T., \& Akinci Çötok, N. (2013). Adaptation of the Short Form of the Oxford Happiness Questionnaire into Turkish: A validity and reliability study. The Turkish Psychological Counseling and Guidance Journal (TPCGJ), 4(36), 165-172.

Flett, G. L., Hewitt, P. L., Blankstein, K. R., \& Gray, L. (1998). Psychological distress and the frequency of perfectionistic thinking. Journal of Personality and Social Psychology, 75, 13631381.

Hills, P., \& Argyle, M. (2002). The Oxford Happiness Questionnaire: A compact scale for the measurement of psychological well-being. Personality and Individual Differences, 33, 10731082.

Holeva, V., Tarrier, N. T., \& Wells, A. (2001). Prevalence and predictors of acute stress disorder and PTSD following road traffic accidents: Thought control strategies and social support. Behavior Therapy, 32, 65-83.

Hu, L. T., \& Bentler, P. M. (1999). Cut off criteria for fit indexes in covariance structural analysis: 
Conventional criteria versus new alternatives. Structural Equation Modeling, 6, 155.

Kacar, M., \& Sarıçam, H. (2015). Sınıf öğretmen adaylarinin üstbiliş farkindalıkları ile matematik kaygı düzeyleri üzerine bir çalışma (The examination of the relationship between metacognitive awareness and math anxiety levels in pre-service primary school teachers). Trakya Üniversitesi Eđitim Fakültesi Dergisi, 5(2), 137-152.

Kenny, C. (2006). The philosophy of happiness. In C. Kenny \& A. Kenny (Eds.), Life, liberty, and the pursuit of utility: Happiness in philosophical and economic thought. Charlottesville, USA: Imprint Academic.

Layard, R. (2005). Happiness: Lessons from a New Science. London: Allen Lane.

Lazarus, R. S. (1991). Emotion and adaptation. New York, NY: Oxford University Press.

Lazarus, R. S., \& Folkman, S. (1984). Stress, Appraisal, and Coping. New York: Springer.

Lindberg, A., Fernie, B. A., \& Spada, M. M. (2011). Metacognitions in problem gambling. Journal of Gambling Studies, 27(1), 73-81.

Lyubomirsky, S., Sheldon, K. M., \& Schkade, D. (2005). Pursuing happiness: The architecture of sustainable change. Review of General Psychology, 9(2), 111-131.

Lyubomirsky, S., \& Tucker, K. L. (1998). Implications of individual differences in subjective happiness for perceiving, interpreting, and thinking about life events. Motivation and Emotion, 22(2), 155-186.

Matthews, G., \& Wells, A. (2004). Rumination, depression, and metacognition: The SREF model. In C. Papageorgiou \& A. Wells (Eds.), Depressive rumination: Nature, theory, and treatment (pp. 125-151). Chichester, England: Wiley.

Mohammadkhani, S. (2013). The role of fusion beliefs and metacognitions in obsessive-compulsive symptoms in general population. Iranian Journal of Clinical Psychology (IJCP), 1(2), 2935 .

Monroe, S. M., \& Simons, A. D. (1991). Diathesisstress theories in the context of life-stress research: Implications for the depressive disorders. Psychological Bulletin, 110, 406-425.

Moorhead, G., \& Griffin, R. W. (1998). Organizational behavior: Managing people and organizations (5th ed.). Boston: Houghton Mifflin.

Morrison, A. P., Wells, A., \& Nothard, S. (2000). Cognitive factors in predisposition to auditory and visual hallucinations. British Journal of Clinical Psychology, 39, 67-78.
Nock, M. K., \& Kazdin, A. E. (2002). Examination of affective, cognitive, and behavioral factors and suicide-related outcomes in children and young adolescents. Journal of Clinical Child and Adolescent Psychology, 31, 48-58.

Omidi. A., Akbari, H., Mahdian, M. (2011). Association of happiness, perceived stress and academic achievement in Kashan University of medical sciences students. Paper presented at the International Conference on Medical, Biological and Pharmaceutical Sciences (ICMBPS'2011) Pattaya.

Örücü, M. C., \& Demir, A. (2009). Psychometric evaluation of perceived stress scale for Turkish university students. Stress and Health, 25, 103109.

Papageorgiou, C., \& Wells, A. (2003). An empirical test of clinical metacognitive model of rumination and depression. Cognitive Therapy and Research, 27, 261-273.

Ricard, M. (2007). Happiness: A guide to developing life's most important skill. UK: Atlantic Books.

Rohan, K. J., Sigmon, S. T., \& Dorhofer, D. M. (2003). Cognitive-behavioral factors in seasonal affective disorder. Journal of Consulting and Clinical Psychology, 71, 22-30.

Rosengren, A., Tibblin, G., \& Wilhelmsen, L. (1991). Self-perceived psychological stress and incidence of coronary artery disease in middleaged men. American Journal of Cardiology, 68, $1171-1175$.

Roussis, P., \& Wells, A. (2006). Post-traumatic stress symptoms: Tests of relationships with thought control strategies and beliefs as predicted by the metacognitive model. Personality and Individual Differences, 40(1), 111-122.

Sagiv, L., Roccas, S., \& Hazan, O. (2004). Value pathways to well-being: Healthy values, valued goal attainment, and environmental congruence. In P. A. L. S. Joseph (Ed.), Positive Psychology in Practice (pp. 68-85). Hoboken, NJ: Wiley.

Sarıçam, H., \& Akın, A. (2015). The Turkish version of the Self Rumination Scale: The study of validity and reliability. Sakarya University Journal of Education (SUJE), 5(1), 55-69.

Seligman, M. E. P. (2002). Authentic happiness: Using the new positive psychology to realize your potential for lasting fulfillment. Simon and Schuster.

Sheldon, K. M., \& Lyubomirsky, S. (2004). Achieving sustainable new happiness: Prospects, practices, and prescriptions. In A. Linley \& S. Joseph 
(Eds.), Positive psychology in practice (pp. 127145). Hoboken, NJ: John Wiley \& Sons.

Sheikh, M., Saadat, S. H., Sarabandi, H., Tabatabaee, S. M., \& Karimian, A. (2013). Comparing metacognitive beliefs and worry in patients with anxiety, depression and non-patients. Der Pharmacia Sinica, 4(6), 59-65.

Siegrist, J. (2008). Chronic psychosocial stress at work and risk of depression: Evidence from prospective studies. European Archives of Psychiatry and Clinical Neuroscience, 258(Suppl 5), 115119.

Sirgy, M. J., \& Wu, J. (2009). The pleasant life, the engaged life, and the meaningful life: What about the balanced life? Journal of Happiness Studies, 10(2), 183-196.

Spada, M. M., Mohiyeddini, C., \& Wells, A. (2008). Measuring metacognitions associated with emotional distress: Factor structure and predictive validity of the metacognitions questionnaire 30 . Personality and Individual Differences, 45, 238242.

Spada, M. M., Nikcevic, A. V., Moneta, G. B., \& Wells, A. (2008). Metacognition, perceived stress, and negative emotion. Personality and Individual Differences, 44(5), 1172-1181.

Spada, M. M., Nikcevic, A. V., Moneta, G. B., \& Wells, A. (2007). Metacognition as a mediator of the relationship between emotion and smoking dependence. Addictive Behaviors, 32, 21202129

Spada, M. M., Nikcevic, A. V., Moneta, G. B., \& Ireson, J. (2006). Metacognition as a mediator of the effect of test anxiety on surface approach to studying. Educational Psychology, 26, 1-10.

Spada, M. M., \& Wells, A. (2008). Metacognitive beliefs about alcohol use: Development and validation of two self-report scales. Addictive Behaviors, 33, 515-527.

Spada, M. M. \& Wells, A. (2006). Metacognitions about alcohol use in problem drinkers. Clinical Psychology and Psychotherapy, 13, 138-143.

Spada, M. M., \& Wells, A. (2005). Metacognitions, emotion, alcohol use. Clinical Psychology and Psychotherapy, 12, 150-155.

Spada, M. M., Zandvoort, M., \& Wells, A. (2006). Metacognitions in problem drinkers. Cognitive Therapy and Research, 31, 709-716.

Sumner, L. W. (1996). Welfare, happiness, and ethics. New York: Oxford University Press.

Tosun, A., \& Irak, M. (2008). Adaptation, validity, and reliability of the Metacognition Questionnaire-30 for the Turkish population, and its rela- tionship to anxiety and obsessive-compulsive symptoms. Turkish Psychiatry Journal, $19(1)$, 67-80.

Vennhoven, R. (2005). Apparent quality of life in Nations. Social Indicators Research, 71, 6168.

Veenhoven, R. (1991). Is happiness relative?. Social Indicators Research, 24, 1-34.

Vitousek, K. M. (1996). The current status of cognitive behavioral models of anorexia nervosa and bulimia nervosa. In P. M. Salkovskis (Ed.), Frontiers of cognitive therapy (pp. 383-418). New York: Guilford Press.

Wellman, H. (1985). The child's theory of mind: The development of conscious cognition. San Diego: Academic Press.

Wells, A. (2009). Metacognitive therapy for anxiety and depression. New York, NY: The Guildford Press.

Wells, A. (2000). Emotional disorders and metacognition: Innovative cognitive therapy. Chichester, UK: Wiley.

Wells, A. (1995). Meta-cognition and worry: A cognitive model of generalized anxiety disorder. Behavioural and Cognitive Psychotherapy, 23, 301-320.

Wells, A., \& Carter, K. (2001). Further tests of a cognitive model of generalized anxiety disorder: Metacognitions and worry in GAD, panic disorder, social phobia, depression, and non-patients. Behavior Therapy, 32, 85-102.

Wells, A., \& Cartwright-Hatton, S. (2004). A short form of the metacognitions questionnaire: Properties of the MCQ-30. Behaviour Research and Therapy, 42, 385-396.

Wells, A., \& Matthews, G. (1994). Attention and emotion: A clinical perspective. Hove, UK: Erlbaum.

Wells, A., \& Papageorgiou, C. (1998). Relationship between worry and obsessive-compulsive symptoms and meta-cognitive beliefs. Behavior Research and Therapy, 36, 899-913.

Wolkowitz, O. M., Epel, E. S., Reus, V. I., \& Mellon, S. H. (2010). Depression gets old fast: Do stress and depression accelerate cell aging? Depress Anxiety, 27, 327-338.

Yılmaz, A. E. (2007). Examination of metacognitive factors in relation to anxiety and depressive symptoms: A cross-cultural study. Unpublished doctoral thesis, Middle East Technical University, Ankara.

Yılmaz, A. E., Gençöz, T., \& Wells, A. (2008). Psychometric characteristics of the Penn 
State Worry Questionnaire and MetaCognitions Questionnaire-30 and metacognitive predictors of worry and obsessive-com- pulsive symptoms in a Turkish sample. Clinical Psychology and Psychotherapy, 15, 424439.

\title{
METAKOGNÍCIE A POCIT ŠŤASTIA: MEDIAČNÁ ÚLOHA VNIIMANÉHO STRESU
}

\author{
H. S a r i ç a m
}

Súhrn: Hlavným ciel'om výskumu bolo skúmat' mediačnú úlohu vnímaného stresu medzi metakogníciami a pocitom št’astia. Výskumu sa zúčastnilo 290 vysokoškolákov. V našej štúdii sme použili Metacognition Questionnaire-MCQ-30, Škálu vnímaného stresu a Skrátený Oxfordský dotazník št’astia. Vzt’ahy medzi metakogníciami, vnímaným stresom a pocitom št’astia sme skúmali pomocou korelačnej analýzy a modelu štrukturálnych rovníc (SEM). Korelačná analýza odhalila negatívny vzt'ah metakognície a vnímaného stresu s pocitom št'astia. Na druhej strane, metakognícia pozitívne korelovala s vnímaným stresom. Model štrukturálnych rovníc ukázal, že metakognícia vedie k zvýšeniu vnímaného stresu u nešt’astnej osoby, zatial’ čo zníženie stresu vedie k št’astiu; metakognícia však prispieva aj k pocitu nešt'astia. Výsledky sme diskutovali v kontexte relevantnej literatúry. 